\title{
Peer Correction On Writing Quality Of College Students Having Different Cognitive Styles
}

\author{
Sri Wahyuni \\ IAIN Kediri, Indonesia \\ wabyu_uni78@yahoo.com
}

\begin{abstract}
This research aims at investigating the effect of peer correction on writing quality of college students' having different cognitive styles. Two groups of students participated in this study. In the treatment, one group conducted peer correction, and the other group conducted self correction on their writings. To collect the data on students' cognitive styles, Group Embedded Figure Test (GEFT) was used. To collect the data on students' writing quality before and after the treatment, writing tests were used. To test the bypotheses, an analysis of covariate (ANCOVA) was used. The results shows that both types of corrections, peer and self corrections, and students' cognitive styles, field dependent and field independent, significantly affects the students' writing quality. However, it seems to be no significant interaction between types of corrections and students' cognitive styles. The types of correction and cognitive styles do not affect students' writing quality at the same time.
\end{abstract}

Key words: peer correction, self correction, writing quality, cognitive styles

\begin{abstract}
Abstrak
Penelitian ini bertujuan menginvestigasi pengarub koreksi sebaya terhadap kualitas tulisan mahasiswa yang mempunyai gaya kognitif yang berbeda. Dua grup mahasiswa berpartisipasi dalam penelitian ini. Di perlakuan, satu grup melakukan koreksi sebaya dan grup yang lain melakukan koreksi sendiri pada tulisan mereka. Group Embedded Figure Test (GEFT) digunakan untuk mengumpulkan data gaya kognitif mahasiswa. Tes Tulis digunakan untuk mengumpulkan data kualitas tulisan mahasiswa sebelum dan sesudah perlakuan. ANCOVA digunakan untuk menguji bipotesis. Hasil penelitian menunjukan babwa kedua jenis koreksi, sebaya dan sendiri, serta gaya kognitif mahasiswa secara signifikan mempengarubi kualitas tulisan mahasiswa. Namun, tidak ada interaksi yang signifikan antara jenis koreksi dengan gaya kognitif mahasiswa. Jenis koreksi dan gaya kognitif tidak mempengarubi kualitas tulisan mahasiswa pada saat yang sama.
\end{abstract}

Kata Kunci: Koreksi sebaya, koreksi sendiri, kualitas tulisan, gaya kognitif

Permalink/DOI: http://dx.doi.org/10.18326/infsl3v12i2.259-282 


\section{Introduction}

Writing is an essential skill for language learners especially in the context of English as a foreign language (EFL). Writing means an activity of creating written words. Through writing, the EFL learners can inform and convey their messages to the readers across places and time. The learners can communicate with other learners from different countries by using English written.

Writing is still considered as difficult skill to learn by Indonesian learners (Widiati and Cahyono, 2006; Muth'im, 2010). According to Heaton (1995: 35), writing skill is complex and sometimes hard to teach; it requires not only mastery of grammatical and rhetorical devices, but also of conceptual and judgment elements. The difficulty and complexity of writing starts at the moment the learners think about his/her topic until the written text has been produced. Similar to Heaton, Harmer (1991: 52) states that writing is the most complicated skill to learn and needs feedback.

Giving error correction in the process of learning how to write is beneficial. The correction given can make the learners more concentrated on what is being learned (Muth'im, 2013: 2). In addition, correction can make learners more aware of their strengths and weaknesses in a learning course. According to Lewis (2002: 3-4), correction is beneficial for both teachers and learners. For teachers, error correction gives information about individual and collective class progress, and indirectly it is a form of evaluation on their own teaching. For learners, error correction is an on going form of assessment which is more focused than marks or grades. In short, error correction is used to help learners improve their learning.

Correction is not only provided by teachers; it can also be provided by peers. Peer correction means having other writers to read and to give correction on what other writer has written (Hyland, 2005). In this research, the writers were college students. Therefore, in this case peer correction means having other Islamic college students to read and to give comments, corrections and suggestions on the writing quality of other Islamic college students. Peer correction was conducted based on peer correction guide that had been given by the lecturer. 
Peer correction in the writing classroom can be an alternative strategy in improving students' writing. Furthermore, when time and class size become problematic, peer correction gives more chances for students to get more language input. Furthermore, the process of peer feedback activities can raise students' social character. Social constructionists believe that knowledge is negotiated and best acquired through interaction (Kurt and Atay, 2007). In addition, al-Qurashi (2009) states that knowledge is best acquired in social context through relationship. In practice, peer feedback allows students to negotiate their strengths and weaknesses (William, 2005; Hyland, 2005). Through peer feedback, the students can negotiate their ideas, comments, corrections and suggestions. This will raise the students' awareness of the importance of peers relationship, and lead to mutual interaction among peers. The most important thing is that peer feedback can raise their respect for other students (peer).

In receiving correction, the different cognitive styles of students may receive it differently. Cognitive style is an individual's natural, habitual, and preferred way of absorbing, processing, and retaining new information and skills (Reid, 1995; Ellis, 1993; Lightbown and Spada, 2006). It has two classifications, field dependent and field independent styles. According to Ellis (1993: 175), field dependent students are individuals who prefer to work in groups; they require extrinsic motivation and more structured reinforcement from others. Field dependent students may receive peer correction as useful input for their writing. However, for field independent students, they may dismiss it as not useful. They are individuals who prefer to have individual work and tend to be intrinsically motivated.

Studies on the role of the students' cognitive styles on students' achievement have been conducted. They found that there is a positive effect of cognitive styles on students' achievement. For instance, a study conducted by Ellis (1993: 175-189) found that cognitive styles affect the way students respond to the instruction they receive and the rate and level of their L2 achievement. Field dependent students tend to be almost exclusively studial in their approach; in contrast, field independent students tend to be more balanced, and give evidence of an ability to operate both studially and experientially. 
The other study that includes cognitive styles as one of the variables is conducted by Rachmi and Rahmawati (2014). They conducted a study on the effect of students' speaking learning techniques (role play and group discussion) and cognitive styles (field independent and field dependent) towards the students' speaking ability. The findings of this research show that field independent students are better taught by using role play techniques, while field dependent students are better taught by using group discussion. These findings also support the theory of Witkin, Moore, Goodenough, and Cox (1977) that field independent students do not rely on the learning environment for referents; they have an internal structure that enables them to analyze information and solve problem without assistance. On the other hand, field dependent students respond best to a learning environment that evokes his/ her feeling and experience; for them learning is a social experience. Based on this reason, this research explores more on the effect of peer correction compared to self correction on argumentative essay of students with different cognitive styles.

The present study was designed to address the research questions as follows; 1) Is there any significant difference on the mean score of students' writing quality between those doing peer correction and those doing self correction? 2) Is there any significant difference on the mean score of students' writing quality between field independent students and field dependent students? 3) Is there any interaction between types of correction and students' cognitive styles on their writing quality?

\section{Correction on Students' Writing}

Some studies on the effect of correction on students' writing have been conducted; however, the findings are still contradictive. Some studies argue that correction does not make students have better writing. Truscott $(1996,2007)$ states that error correction should be abandoned in writing courses since it diverts time and energy away from the more productive aspects of a writing program. Truscott and Hsu's study (2008) revealed that the corrections do not have impact on students' writing development. They claim that 
the improvements made during revisions are not evident on the effectiveness of correction for improving students' writing ability (Truscott and Hsu, 2008: 292).

However, other studies argue that correction makes learners write better (e.g. Ferris, 1999; Bitchener, Young, and Cameron, 2005). Ferris' study (1999) revealed that correction in general is impossible to be dismissed as it depends on the quality of the correction; it will work if the correction is clear and consistent. A study conducted by Bitchener et.al (2005) found that the provision of correction on students' writing can improve their accuracy in writing.

Furthermore, Tsui and NG (2000) conducted a study on a secondary school found that peer correction contributes positively to the students' writing. Although the students tend to favor the teacher correction, peer correction on students' writing improves a sense of audience, raises students' awareness of their own strengths and weaknesses of their writing, encourages collaborative learning and fosters the ownership of text. Relating to this finding, the present study conducts a study on investigating the effectiveness of peer correction on argumentative essay of tertiary level students.

In addition, Kwok (2008) investigates students' perceptions of peer evaluation and teachers' role in a seminar discussion of secondlanguage university level in Hong kong. He found that students' evaluation and comments are considered fair, useful and sufficient by peers. Different with this study, the present study focuses on investigating the effectiveness of peer correction compared to self correction on students' essay writing.

\section{Research Method}

This study employs a quasi experimental research design. The reason is that the present study is conducted during regular classes, so it is impossible to randomize the participants to the intended conditions. Reassigning the students to different classrooms in order to get the intended group for the sake of the experiment is not allowed. Therefore, the present study uses the existing classes of students. The research design of this study is illustrated in Figure 1. 


\begin{tabular}{|c|c|c|c|}
\hline Group & Pre-Test & Treatment & Post-Test \\
\hline $\begin{array}{l}\text { Experimental } \\
\text { group }\end{array}$ & $\sqrt{ }$ & $\begin{array}{l}\text { Peer corrective } \\
\text { feedback }\end{array}$ & $\sqrt{ }$ \\
\hline$\uparrow$ & - & - & \\
\hline $\begin{array}{c}\text { Selected using } \\
\text { simple sampling } \\
\text { (lottery) } \\
\downarrow\end{array}$ & & & \\
\hline Control group & $\sqrt{ }$ & Self Correction & $\sqrt{ }$ \\
\hline
\end{tabular}

Figure 1.

The Research Design

Three variables are used in this study: independent variable (the types of correction-peer correction and self correction), dependent variable (the students' writing quality on argumentative essay), and moderator variable (the students' cognitive styles-field dependent and field independent students). Moderator variable is the variable that might affect the relationship between independent variable and dependent variable. It is supposed to moderate and control the main effect of the main independent variable to the dependent variable. The students' cognitive style is assumed to have effect on the students' writing quality. The experimental condition of this study can be seen in Table 1 .

Table 1.

The Experimental Condition

\begin{tabular}{lcc}
\hline \multicolumn{1}{c}{ Students' cognitive } & \multicolumn{2}{c}{ Types of correction } \\
\cline { 2 - 3 } style & Peer correction & Self correction \\
\hline Field dependent & $\sqrt{ }$ & $\sqrt{ }$ \\
Field independent & $\sqrt{ }$ & $\sqrt{ }$ \\
\hline
\end{tabular}

The fourth semester of English students at Kediri become the population of this study. There are six classes, and each class 
consists of 25-35 students. They are taking Writing 3 which focuses on writing several types of essay including argumentative essay. Then class A consisting of 32 students and class B consisting of 35 students become the sample. The students of both classes have quite similar characteristics especially in terms of their writing ability.

The instruments of the present study are Group Embedded Figure Test (GEFT) and writing test. GEFT is a standardized test that has been used as a reliable instrument in measuring the cognitive style of students. The classifications of cognitive styles are fielddependent and field-independent students. In the scoring, the Group Embedded Figure Test used the discrete point. In this test, each correct answer got score 1, and incorrect answer got 0 . The total score of this test was eighteen points. The students who got score 0-9 were categorized as field dependent students' cognitive style. Furthermore, the students who got score 10-18 were categorized as field independent students.

Then writing test is used to collect the data about students' writing quality on argumentative essay. Three writing tests are used in this study. The topic of the first writing test is "Should Islamic college students choose their own courses". Then the topic of the second writing test is "Should Islamic college students wear uniform". For the last writing test, the students are asked to write an essay based on the topic "Should Islamic college students join students association". To score the students' writings, an analytical scoring rubric adopted from Jacob (1981) for argumentative essay is used. It consists of five components: content, organization, vocabulary, language use and mechanics.

The both groups, the experimental and the control groups get pre-test before getting the treatment. In the pretest, the both groups are asked to write an argumentative essay on certain topic. After getting the pre-test, the treatments are given to the both groups. The experimental group conducts peer correction, and the control group conducts self correction on their essays. After getting the treatments, the both groups get post-test. In the post-test, the both groups, the experimental and the control groups are asked to write new argumentative essay. Table 2 presents the schedule of the treatment. 
Table 2.

The Schedule of the Treatment

\begin{tabular}{|c|c|c|}
\hline Meeting & $\begin{array}{c}\text { The Experimental } \\
\text { Group }\end{array}$ & The Control Group \\
\hline I & \multicolumn{2}{|c|}{ Examining the students' cognitive styles } \\
\hline II & \multicolumn{2}{|c|}{ Administering Writing test 1 (Pre-Test) } \\
\hline III & $\begin{array}{l}\text { Conducting peer } \\
\text { correction for the } \\
\text { first writing and } \\
\text { understanding the } \\
\text { correction }\end{array}$ & $\begin{array}{c}\text { Conducting self correction } \\
\text { for the first writing } \\
\text { and understanding the } \\
\text { correction }\end{array}$ \\
\hline IV & \multicolumn{2}{|c|}{ Administering writing test 2} \\
\hline $\mathrm{V}$ & $\begin{array}{l}\text { Conducting peer } \\
\text { correction for the } \\
\text { second writing and } \\
\text { understanding the } \\
\text { correction }\end{array}$ & $\begin{array}{l}\text { Conducting self correction } \\
\text { for the second writing } \\
\text { and understanding the } \\
\text { correction }\end{array}$ \\
\hline VI & \multicolumn{2}{|c|}{ Administering writing test 3 (Post-Test) } \\
\hline
\end{tabular}

In analyzing the data, a parametric test, Analysis of Covariate (ANCOVA) is employed by using SPSS. The reason for using ANCOVA is the present study's use of existing classes. Consequently, the score of the pre-test becomes the covariate of the analysis.

\section{Analysis}

Before ANCOVA was conducted, some statistical assumptions needed to be fulfilled. They are the assumption of normal distribution, the assumption of homogeneity variance, and the assumption of linier relationship between covariates and dependent variable

Normality Testing

The first assumption that should be fulfilled before ANCOVA was conducted was the testing of normal distribution of the data. Based on DÖrnyei (2007), the criteria of the data normality testing 
can be seen from the result of the general level of significance in Kolmogorov-Smirnov scale; the distribution of data was normal if Sig. $\geq .05$. The summary result of computation can be seen in Table 3 .

Table 3. The Summary of the Result of the Normality Testing

\begin{tabular}{clccc}
\hline \multirow{2}{*}{ Group of participants } & \multicolumn{3}{c}{ Kolmogorov-Smirnov } \\
\cline { 3 - 5 } & & Statistic & df & Sig. \\
\hline \multirow{2}{*}{ pretest } & experimental group & .121 & 22 & .200 \\
\cline { 2 - 5 } & control group & .137 & 24 & .200 \\
\hline \multirow{2}{*}{ posttest } & experimental group & .130 & 22 & .200 \\
\cline { 2 - 5 } & control group & .151 & 24 & .167 \\
\hline
\end{tabular}

From Table 3, it can be seen that the highest obtained value was .200, and the smallest obtained value was .167.The whole obtained values exceeded the level of significance in KolmogorovSmirnov (.05); therefore, the whole data did not deviate from the normal distribution. The whole data produced by the samples looked like a bell-shaped curve. Since the distributions of the data were normal, the data fulfilled the criteria to be used to test the hypotheses.

\section{Homogeneity Variance Testing}

The next statistical assumption that should be fulfilled is testing the homogeneity variance. In line with DÖrnyei (2007), Levene's test for equality of variances was employed in this study to fulfill the assumption of homogeneity of variance. The data variances were equally homogeneous if Sig. $\geq .05$. Table 4 presents the test result of homogeneity variances in the present study.

Table 4.

The Homogeneity Testing of Variance Results

\begin{tabular}{cccc}
\hline F & df1 & df2 & Sig. \\
\hline 2.654 & 3 & 42 & .061 \\
\hline
\end{tabular}


From the table above, it can be seen that the result of homogeneity testing of variances was .061 which is higher than .05 (the significance level of Levene's Test). Hence, the data variance was homogenous. The underlying assumption of homogeneity of variance has been met. Since the data distributions were normal, and the data variance was homogenous, it can proceed to analyze the data using parametric test.

\section{Linearity Testing}

To be able to proceed with ANCOVA analysis, there must be a significant relationship between the covariate and the dependent variable. The significant value obtained must be smaller than the significant level $(\mathrm{p}<.05)$. In the analysis, the covariate is included to control the differences on the independent variable. The primary purpose of covariate testing is evaluating the relationship between the covariate and the dependent variable. Table 5 presents the testing result of a linier relationship between covariate and the dependent variable.

Table 5.

The Testing Result of Linearity

\begin{tabular}{lcccccc}
\hline \multicolumn{1}{c}{ Source } & $\begin{array}{c}\text { Type III Sum } \\
\text { of Squares }\end{array}$ & df & $\begin{array}{c}\text { Mean } \\
\text { Square }\end{array}$ & F & Sig. & $\begin{array}{c}\text { Partial Eta } \\
\text { Squared }\end{array}$ \\
\hline Corrected Model & $2158.684^{\mathrm{a}}$ & 4 & 539.671 & 6.360 & .000 & .383 \\
Intercept & 796.027 & 1 & 796.027 & 9.381 & .004 & .186 \\
Group strategy & 621.247 & 1 & 621.247 & 7.321 & .010 & .152 \\
Cognitive styles & 661.461 & 1 & 661.461 & 7.795 & .008 & .160 \\
Pretest score & $\mathbf{8 0 1 . 5 1 9}$ & $\mathbf{1}$ & $\mathbf{8 0 1 . 5 1 9}$ & $\mathbf{9 . 4 4 5}$ & $\mathbf{. 0 0 4}$ & $\mathbf{. 1 8 7}$ \\
strategy * cognitive & 101.509 & 1 & 101.509 & 1.196 & .280 & .028 \\
styles & 3479.229 & 41 & 84.859 & & & \\
Error & 322200.000 & 46 & & & & \\
Total & 5637.913 & 45 & & & & \\
Corrected Total & & & & & &
\end{tabular}

a. R Squared $=.383($ Adjusted $\mathrm{R}$ Squared $=.323)$ 
Table 3 shows that the obtained significant value of a linier relationship between covariate and the dependent variable testing was .004. It was smaller than the significant level $(.004<.05)$. It means that there is a linier relationship between the covariate and the dependent variable. Therefore, the assumption was met, and it can proceed with ANCOVA analysis.

\section{The Result of ANCOVA}

ANCOVA is used to test the hypotheses of the present study. As mentioned previously, there are three research questions to be answered. To answer the research question, this research starts with examining the main effect of peer correction and students' cognitive styles on students' writing quality. Then it continues to examine the interaction effects of those independent variables on students' writing quality. The result of ANCOVA computation is presented in Table 6. The testing of the hypotheses of the study are presented one by one in the next section.

Table 6.

The Result of Between Subject Effects Test

\begin{tabular}{lcccccc|}
\hline \multicolumn{1}{c}{ Source } & $\begin{array}{c}\text { Type III Sum } \\
\text { Of Squares }\end{array}$ & df & $\begin{array}{c}\text { Mean } \\
\text { Square }\end{array}$ & F & Sig. & $\begin{array}{c}\text { Partial Eta } \\
\text { Squared }\end{array}$ \\
\hline Corrected Model & $2158.684^{\mathrm{a}}$ & 4 & 539.671 & 6.360 & .000 & .383 \\
Intercept & 796.027 & 1 & 796.027 & 9.381 & .004 & .186 \\
Group strategy & $\mathbf{6 2 1 . 2 4 7}$ & $\mathbf{1}$ & $\mathbf{6 2 1 . 2 4 7}$ & $\mathbf{7 . 3 2 1}$ & $\mathbf{. 0 1 0}$ & $\mathbf{. 1 5 2}$ \\
Cognitive styles & $\mathbf{6 6 1 . 4 6 1}$ & $\mathbf{1}$ & $\mathbf{6 6 1 . 4 6 1}$ & $\mathbf{7 . 7 9 5}$ & $\mathbf{. 0 0 8}$ & $\mathbf{. 1 6 0}$ \\
Pretest score & 801.519 & 1 & 801.519 & 9.445 & .004 & .187 \\
strategy * & $\mathbf{1 0 1 . 5 0 9}$ & $\mathbf{1}$ & $\mathbf{1 0 1 . 5 0 9}$ & $\mathbf{1 . 1 9 6}$ & $\mathbf{. 2 8 0}$ & $\mathbf{. 0 2 8}$ \\
cognitive styles & 3479.229 & 41 & 84.859 & & & \\
Error & 322200.000 & 46 & & & & \\
Total & 5637.913 & 45 & & & & \\
Corrected Total & & & &
\end{tabular}

a. R Squared $=.383$ (Adjusted R Squared $=.323$ ) 


\section{a. Testing the First Hypothesis}

The first hypothesis to be tested is examining the main effect of peer correction on the quality of students' writing. It has been transformed into a statistical hypothesis as follow.

H1 : There is significant difference on the mean score of students' writing quality between those doing peer correction and those doing self correction.

Ho :There is no significant difference on the mean score of students' writing quality between those doing peer correction and those doing self correction.

The analysis result that is presented in Table 6 above labeled group strategy shows that the significance value obtained was .010. It was smaller than the significance level $(.010<.05)$. Therefore, there is enough evidence to reject the null hypothesis. Since the null hypothesis could be rejected, statistically there is significant difference on the mean score of students' writing quality between those doing peer correction and those doing self correction. The next question is which group of students has the better writing quality, the students doing peer correction or those doing self correction. Therefore, the finding of descriptive statistic needs to be performed as follows.

Table 7.

The Descriptive Statistic

\begin{tabular}{|c|c|c|c|c|}
\hline Group strategy & Cognitive styles & Mean & Std. Deviation & $\mathrm{N}$ \\
\hline \multirow{3}{*}{$\begin{array}{l}\text { peer correction/ } \\
\text { experimental } \\
\text { group }\end{array}$} & field independent & 83,24 & 10.509 & 17 \\
\hline & field dependent & 68.40 & 6.148 & 5 \\
\hline & Total & 79.86 & 11.482 & 22 \\
\hline \multirow{3}{*}{$\begin{array}{l}\text { self correction/ } \\
\text { control group }\end{array}$} & field independent & 87.40 & 8.675 & 15 \\
\hline & field dependent & 83.11 & 12,791 & 9 \\
\hline & Total & 85.79 & 10,354 & 24 \\
\hline \multirow[t]{3}{*}{ Total } & field independent & 85.19 & 9.770 & 32 \\
\hline & field dependent & 77.86 & 12.877 & 14 \\
\hline & Total & 82.96 & 11.193 & 46 \\
\hline
\end{tabular}


From Table 7 above, it can be seen that the total mean score of students' writing quality doing self correction was higher than the total mean score of students' writing quality doing peer correction $(79.86<85.79)$. The interpretation of this result is that self correction makes students' writing quality better than peer correction.

\section{b. Testing the Second Hypothesis}

The second hypothesis is examining the main effect of students' cognitive styles on the quality of students' writing. It has been transformed into a statistical hypothesis as follows.

H1 : There is significant difference on the mean score of students' writing quality between field independent students and field dependent students.

Ho : There is no significant difference on the mean score of students' writing quality between field independent students and field dependent students.

The analysis result which is presented in Table 6 above labeled cognitive styles shows that the significance value obtained was .008. It was smaller than the significance level $(.008<.05)$. Since the significant value obtained was lower than the significant level, there is enough evidence to reject the null hypothesis. Since the null hypothesis could be rejected, statistically there is significant difference on the mean score of students' writing quality between field independent students and field dependent students. The next question is which group of students has better the writing quality, field independent or field dependent students.

Table 7 above shows the result of descriptive statistic of the analysis. The field independent students in the experimental and control groups achieved higher mean score on the quality of their writing than the mean score of field dependent students in the both groups. It means that students with field independent cognitive style tend to have better writing quality than students with field dependent cognitive style. 


\section{c. Testing the Third Hypothesis}

The third hypothesis is examining the interaction effect between types of correction and students' cognitive styles on their writing quality. It has been transformed into a statistical hypothesis as follows.

$\mathrm{H}_{1} \quad$ : There is an interaction between types of correction and students' cognitive styles on their writing skill.

Ho : There is not any interaction between types of correction and students' cognitive styles on their writing quality.

The result of the analysis presented in Table 6 labeled strategy * cognitive styles shows that the significance value obtained was .280 which was higher than the significance level $(.280>.05)$. Therefore, there is not enough evidence to reject the null hypothesis. Since the null hypothesis could not be rejected, statistically there is no significant interaction between types of correction and students' cognitive styles on the quality of their writing. Then it is reasonable to believe that the difference in mean score between the writing quality of field independent students and that of field dependent students is equal for two types of correction, peer correction and self correction. Then the three analysis mentioned above are discussed one by one in the following section.

The Effect of Peer Correction Compared to Self Correction on Students' Writing Quality

The finding of the first research question about the effect of peer correction compared to self correction on students' writing quality shows that statistically there is significant difference on the mean score of students' writing quality between those doing peer correction and those doing self correction when pretest score becomes covariate. The ANCOVA computation revealed that significance value obtained was lower than the significance level $(\mathrm{p}$ $<\mathrm{a} ; .010<.05)$. It means that the both types of correction, peer and self corrections affect the quality of students' essay writing. 
This finding is in line with the theory that correction has effect on the quality of students' essay writing quality. It supports Ferris' study (1999). He found that correction influence the students' writing. He said that if the correction is clear and consistent, it will have effect on students' writing. Similar to Ferris, Bitchener et al. (2005: 191) revealed that the provision of correction can increase the students' accuracy in writing. In addition, correction in the process of writing can make the students more concentrated on what is being learned (Muth'im, 2013: 2). In line with Muth'im, Lewis (2002: 3-4) stated that correction is beneficial for both teachers and learners. For teachers, feedback gives information about individual and collective class progress, and indirectly it is a form of evaluation on their own teaching. For learners, feedback is an on going form of assessment which is more focused than marks or grades.

Unexpectedly, the result of descriptive statistics analysis revealed that the total mean score of the quality of students' essay writing conducting self correction was higher than the total mean score of the quality of students' essay writing conducting peer correction $(79.86<85.79)$. It means that the students doing self correction on their own writing had better writing quality than that of those doing peer correction. In other words, the students benefited more from doing self correction than from peer correction. There are some possible reasons of this finding namely the use of peer/ self correction guide and the quality of peer corrective feedback given.

The first possible reason is the use of peer and self correction guides. In conducting peer and self correction, the both groups of students got editing/correcting guide made by the lecturer. One group of students analyzed, corrected, and gave comment on their peer's writing based on this guidance. The other group analyzed, corrected, and gave comments on their own writing also based on this guidance. The difference was just the source of correction, from peer and from self.

The use of the guidance made them easier and more precisely in analyzing, correcting, and giving comments on the draft. Since the both groups have same access and guidance in analyzing, 
correcting, and giving comments on the draft, the students may believe more on their selves in providing the corrections that led to improvement in their writing quality than peer. This finding supports Leki's study (1990) which found that there were some problems with peer comments namely students tend to give corections on surface errors instead of semantic or textual ones, give advice that does not facilitate revision, and have difficulties in deciding whether or not the corrections of their peer are valid.

The next reason is the quality of peer correction given. The participants of the study were FL/L2 writers, and they might not trust the correction of their peer. It is in line with Nelson and Murphy's study (1993) which found that L2 students may not trust their peers' corrections to their writings because they are not native speakers of English. In addition, FL/L2 students coming from cultures that see the teacher as the only source of authority may consider their peers not knowledgeable enough to make sensible corrections and ultimately not incorporate the corrections into their writing.

Moreover, the students' perception on the usefulness of peer correction also affects the result of this study. It is line with Bryant and Carless' study (2009) which found that the perceptions of students about the usefulness of peer correction follow from their perspectives on the quality of peer correction, peer language proficiency, and the novelty or repetitiveness of its process. They stated that peer correction was less favored when students were not able to receive the useful peer correction given, and in this case they tended to prefer teacher correction which was more authoritative. Peer correction was often considered inadequate because it was insufficient critical or the partner lacked the requisite knowledge.

\section{The Effect of Cognitive Styles on Students' Writing Quality}

The next finding of this research shows that statistically there is significant difference on the mean score of the quality of students' writing between field independent and field dependent students. The ANCOVA computation revealed that significance value obtained was lower than the significance level $(\mathrm{p}<\mathrm{a} ; .008<.05)$. It means 
that cognitive styles either field independent or field dependent influences the quality of students' essay writing.

The finding of this research is in line with the theory that cognitive styles affect the students' learning and achievement. This finding is line with Ellis' study (1993) and Rachmi and Rahmawati (2014). Ellis (1993a: 175-189) found that the students' cognitive styles affect the way they respond to the instruction they receive and the rate and level of their L2 achievement. He also characterized that field dependent learners tend to be almost exclusively studial in their approach; meanwhile, field independent learners tend to be more balanced, and give evidence of an ability to operate both studially and experientially. Furthermore, Rahmi and Rahmawati (2014) also found that students who have different cognitive styles receive effective learning instruction differently. Their study revealed that field independent (FI) students are better taught by using role play techniques, while field dependent students (FD) are better taught by using group discussion.

The result of descriptive statistical analysis of this study shows that the mean score of the writing quality of field independent (FI) students is higher than the mean score of the writing quality of field dependent (FD) students. It means that the FI students' cognitive style tends to have better quality of the writing than FD students' cognitive style. There are two possible reasons of this finding namely the characteristics of students' cognitive styles and writing itself.

The first reason is the characteristics of students' cognitive styles. As Witkin, Moore, Goodenough, and Cox (1977) characterized that FI students do not rely on the learning environment for referents; they have an internal structure that enables them to analyze information and solve problem without assistance. In contrast, field dependent students respond best to a learning environment that evokes his/her feeling and experience; for them learning is a social experience in which they need assistance form others.

The next reason is the characteristic of writing. Writing is an individual's activity to produce ideas, thought, and feeling onto papers to be read by others. According O'Malley and Pierce (1996) Writing is personal act in which writers take ideas or prompts and 
transform them into "self initiated" topics. Hence, based on those characteristics, it is reasonable that FI students tends to have more fluent writing skill and better quality of writing than FD students.

Insignificant Interaction Effect between Types of Correction and Cognitive Styles on Students' Writing Quality

The aim of the this study was to investigate whether different types of correction and students' cognitive styles affect their' writing quality. In the beginning it was thought that types of correction interacted with students' cognitive styles on their writing quality. It was proved by the result of this study in which field independent (FI) students had better quality of writing than all of field dependent (FD) students. The lack of interaction between types of correction and students' cognitive styles on their writing quality could be attributed to the roles of individual differences. It is in line with Guénette's study (2007) which found that there are other dimensions of correction on writing skill such as students' ability to engage with correction, the type of errors, the inconsistency of correction provided by teacher, students' perceptions and preferences, and individual differences.

Unexpectedly, this study did not detect any evidence for significant interaction between different types of correction and students' cognitive styles on their writing quality. The result of ANCOVA shows that the obtained significance value was .280, and it was greater than the significance level $(.280>.05)$. It means that the effect of corrections, peer and self corrections, on the quality of students' writing does not depend on the types of cognitive styles, FI and FD. In other words, types of correction and cognitive styles do not affect students' writing quality at the same time. The FI or FD students can have better quality of writing when they conduct correction, both by peer or own selves.

Some possible reasons of insignificant interaction between types of correction and cognitive styles as well as the limitation of the present study can be identified. The first possible reason of insignificant interaction between types of correction and cognitive 
styles is the number of the sample. Some scholars have agreed that in experimental procedure there are at least 15 participants in each group (Dörnyei, 2007). Meanwhile, in this study, the number of participants was 22 students for the experimental group and 24 for the control group. However, it can be argued that the small sample size may not have allowed confidence that the difference between the two groups was real. If the participants number is greater (more than 100), the interaction effect between types of correction and cognitive styles on the quality of students' writing might be significant. As Heriyawati (2015:50) said that the participants number can also affect the variables significance.

The next possible source is the number of the rater. The rater of the students' writings in this study was only the researcher herself due to the limited time in scoring the students' writing. The researcher scored the students' writing based on an analytical scoring rubric adapted from Jacobs et al. (1981) in which it has been tested empirically as a reliable instrument to measure English composition (Kondo-Brown, 2002: 9; Cahyono, 2002: 61). Then the careful specification of an analytical scoring rubric can increase the rater reliability (Brown, 1996). However, the number of rater might also influence the quality of the scoring. The use of more than one rater will have better scoring quality and decreasing more on subjectivity of the scoring.

According to the result of this study, it was proposed that other factors may affect the students in receiving and understanding the correction on their writing such as their language proficiency. It is in line with Lee's study (2008) which was revealed that other factors such as the students' proficiency level took more roles on the way they understand the correction and the ability to engage with the correction given. High proficient students are more positive in terms of their understanding the correction, the ability to correct the errors, and the view of the usefulness of correction than low proficient students.

The finding of this research does not support the previous studies which reveal that cognitive styles affect the types of instructions. It does not support Ellis' research (1993a) which found 
that cognitive styles affect the way students respond to the instruction they receive and the rate and level of their L2 achievement. In addition, it does not support Rahmi and Rahmawati' research (2014) which found that students having different cognitive styles receive effective learning instruction differently. They found that field independent (FI) students are better taught using role play techniques, while field dependent (FD) students are better taught using group discussion.

Those different findings may result from the research itself which is conducted from different perspective. As Guenétte (2007: 40) stated that the different findings can be attributed to the design of the research and methodology, as well as to the presence of external variables that were beyond the control and vigilance of the researcher. In line with Guenétte, Ferris (2004) states that the inconsistencies of research design becomes the reason of conflicting findings.

\section{Conclusion}

Based on the data analysis above, some conclusions can be drawn. First, both types of correction, peer and self corrections, and cognitive styles, field dependent and field independent, significantly affects the quality of students' writing. Next, there is no interaction effect between types of corrections and cognitive styles on the quality of students' writing. This implies that types of correction and cognitive styles do not affect the quality of students' writing at the same time. The students who are field independent or field dependent can have better writing quality when they conduct correction, both by peer or own selves. In other words, no matter the students' cognitive styles, they write better when they do correction on their writing.

According to the finding of this research, some recommendation can be addressed to the writing teachers and further researcher. For writing teachers, peer or self correctionon on their writing class can be an alternative strategy in teaching writing to help students having better quality of writing. Furthermore, various and challenging correction provision can be applied to avoid students' 
boredom in the implementation. They should also introduce the types of correction to the students to make them familiar with and unconfused about the correction.

Next, further research could be conducted on the same area by considering the research findings and the limitations of the present study. First, the subjects of the present study were forty six students at the fourth semester of English Department. With regard to this, it is suggested for the future researchers to replicate the study with different levels of students and bigger number of students. Then the number of the rater should become consideration in scoring the students' writing. It is recommended for further researchers to employ more than one rater to avoid subjectivity in scoring and increase the objectivity of the study.

\section{Bibliography}

Al-Qurashi, F.M. 2009. "Saudi Students' Reactions to Peer Response Groups in EFL Composition Classroom". Journal of King Saudi University, Vol. 21: 57-67.

Bitchener, J., Young, S. \& Cameron, D. 2005. "The Effect of Different Types of Corrective Feedback on ESL Student Writing". Journal of Second Language Writing, Vol. 14: 191-205.

Brown, J.D. 1996. Testing in Language Programs. New Jersey: Prentice Hall Regents.

Bryant, D. A. and Carless, D. R. 2009. "Peer Assessment in a TestDominated Setting: Empowering. Boring or Facilitating Examination Preparation?" Springer, Educ Res Policy Prac. DOI. 10007/s10671-009-9077-2

Cahyono, B. Y. 2002. "Maintaining Process and Improving Grammar Use in Writing." Melbourne Papers in Linguistics and Applied Linguistics, Vol. 1: 57-68.

DÖrnyei, Z. 2007. Research Methods in Applied Linguistics. Oxford: Oxford University Press.

Ellis. R. 1993. Classroom Learning Styles and Their Effect on Second Language Acquisition: A Study of Two Learners. In 
Ellis, R. 1993.Second Language Acquisition and Language Pedagogy,pp.163-174. Clevedon: Multilingual Matters LTD.

Ferris, D. R. 1999. "The Case for Grammar Correction in L2 Writing Classes; A Response to Truscott (1996)". Journal of Second Language Writing, Vol. 8: 1-11.

Ferris, D. R. 2004. "The "Grammar Correction" Debate in L2 Writing: Where Are We, and Where Do We Go from Here? (and What Do We Do in the Meantime?)". Journal of Second Language Writing, Vol. 13: 49-62.

Guenétte, D. 2007. "Is Feedback Pedagogically Correct? Research Design Issues in Studies of Feedback on Writing". Journal of Second Language Writing, Vol. 16, 40-53.

Harmer, J. 1991. The Practice of English Language Teaching. New York: Longman.

Heaton, J. B. 1995. Writing English Language Test. New York: Longman.

Heriyawati, D.V. 2015. Working Memory Capacity, Content Familiarity, and Reading Comprehension. Unpublished Dissertation. English Language Teaching. Graduate program. Malang: State University of Malang.

Hyland, K. 2005. Second Language Writing. Cambridge: Cambridge University Press.J. B. 1981. Testing ESL Composition: A Practical Approach. Rowley, MA: Newbury House.

Jacobs, H. L., Zingraf, S. A., Wormuth, D. R., Hartfiel, V. F, \& Hughey, J.B. 1981. Testing ESL Composition: A Practical Approach. Rowley, MA: Newbury House.

Kondo-Brown, K. 2002. "'A FACETs Analysis of Rater Bias in Measuring Japanese Second Language writing Performance". Language Testing Journal, Vol. 19: 3-31.

Kurt and Atay. 2007. "The Effect of Peer Feedback on the Writing Anxiety of Prospective Turkish Teachers of EFL". Journal of Theory and Practice in Education.

Kwok, L. 2008. "Students' Perceptions on Peer Evaluation and 
Teachers' Role in Seminar Discussions". Electronic Journal of Foreign Language Teaching, Vol. 5, No.1: 84-97.

Lee, I. 2008. "Student Reactions to Teacher Feedback in Two Hong Kong Secondary Classrooms". Journal of Second Language Writing, Vol. 17: 144-165

Leki, I. 1990. "Potentials Problems with Peer Responding in ESL Writing Classes". CATESOL Journal, Vol. 3: 5-17.

Lewis, M. 2002. Giving Feedback in Language Classes. Singapore: SEAMEO Regional Language Centre.

Lightbown, P. M. \& Spada, N. 2006. How Languages are Learned, Third Edition. Oxford: Oxford University Press.

Muth'im, A. 2010. EFL Learners' Ability in Writing ComparisonContrast Essays. In B.Y. Cahyono (Ed.), Second Language Acquisition and English Language Teaching (pp. 105-115). Malang: State University of Malang (UM Press).

Muth'im, A. 2013. The Effectiveness of Indirect Error Correction Feedback on the Quality of Students' Writing. Unpublished Dissertation. Malang: State University of Malang.

Nelson, G. L. \& Murphy, J. M. 1993. "Peer Responce Groups: Do L2 Writers Use Peer Comments in Revising Their Drafts?". TESOL Quarterly, Vol. 27: 135-142.

O'Malley, J.M. and Pierce, L.V. 1996. Authentic Assessment for English Language Learning, Practical Approach for Teacher. New York: Addison-Wesley.

Rachmi \& Rahmawati, D. 2014. "The Effect of Students' Speaking Learning Techniques (Role Play and Group Discussion) and Cognitive Styles (Field Independent and Field dependent) towards Students' Speaking Ability". Proceeding of the Sixty First TEFLIN International Conference 2014: 142-144.

Reid, J. (Ed). 1995. Learning Styles in the ESL/EFL Classroom. New York: Heinle \& Heinle.

Truscott, J. 1996. "The Case Against Grammar Correction in L2 Writing Classes". Language Learning, Vol. 46: 327-369. 
Truscott, J. 2007. "The Effect of Error Correction on Learners' Ability to Write Accurately". Journal of Second Language Writing, Vol. 16: 255-272.

Truscott, J. \& Hsu, A. Y. 2008. "Error Correction, Revision, and Learning". Journal of Second Language Writing, Vol. 17: 292305.

Tsui, A. B. M. \& NG, M. 2000. "Do Secondary L2 Writers Benefit from Peer Comments?". Journal of Second Language Writing, Vol. 9, No. 2: 147-170.

Widiati, U. \& Cahyono, B.Y. 2006. "The Teaching of EFL Writing in the Indonesian Context: the State of Art". Journal Ilmu Pendidikan, Vol. 13, No. 3: 139-150.

Williams, J. 2005. Teaching Writing in Second and Foreign Language Classroom. New York: McGraw Hill.

Witkin, H.A., Moore, C.A., Goodenough, D.R., and Cox, P.W. 1977. "Field Dependent and Field Independent Cognitive Styles and Their Educational Implications". Review of Educational Research, Vol. 47, No. 1(Winter): 1-64. 